BIGELOW, W. G. (1942), "Modern Conception and Treatment of Frostbite," Canad. M.A.J., 47, 529.

BLACKWOOD, W. (I944)," "Pathologist Looks at Ischaemia," Edin. M.J.,

51, I3I.
BLACKWOOD, W. (I944), "Studies in Pathology of Human "Immersion Foot," "Brit. J. Surg., 31, 322.

BOYD, W. (I942), Surgical Pathology (W. B. Saunders Coy., Philadelphia).

BUERGER, L. (1924), The Circulatory Disturbances of the Extremities, including Gangrene, Vasomotor and Trophic Disorders (W. B. Saunders Coy., Philadelphia).

CLARK, W. E. Le Gros. (1945), The Tissues of the Body' (Oxford University Press, Oxford).

DA.VIS, L., SCARFF, J. E., ROGERS, N., and DICKINSON, M. (1943), "High Altitude Frostbite," Surg. Gynec. and Obst., 77, 56r.

DUCUING, J., d'HARCOURT, J., FOLCH, A., and BOFILL, J. (1940), "Les troubles trophiques des extrémités produits par le froid sec en pathologie de guerre," J. de chir., 55, 385 .

FFRENCH, G. E. (1944), "Spontaneous Thrombosis of Axillary Vein,"

Brit. M. J., 2, 277.
GLOBUS, J. H. (I938), "Massive Cerebral Haemorrhage," Proc. Ass. Res. Nerv. Ment. Dis., 18, 1937, 438.

GRANT, R. T. (1940), "Observations on Periarteritis Nodosa," Clin. Sc., $4,245$.

GRIFFITHS, D. L. (1940), "Volkmann's Ischaemic Contracture," Brit. J. Surg., 28, 239.

MAKINS, G. H. (IgIg), Gunshot Injuries to the Blood Vessels (John Wright \& Sons, Bristol).
MAXIMOW, A. A., and BLOOM, W. (1938), A Textbook of Histology (W. B. Saunders Coy., Philadelphia).

PICKERING, G. W. (I943), "Circulation in Arterial Hypertension," Brit. M.J., 2, I and $3 \mathrm{I}$.

KREYBERG, L. (1945), "Some Notes and Considerations Regarding $\mathbb{Q}$ Injuries from Cold. Io8th (U.S.) General Hospital (to be published). $c$

LEARMONTH, J. R. (1943), "Reflex Vasodilatation in Surgery," Edin."

M.J., 50, I4O.
LEARMONTH, J. R., BLACKWOOD, W., and RICHARDS, R. L. $\overrightarrow{\overline{\vec{H}}}$ (I944), "Localised Arterial Thrombosis of Indeterminate Origin," Edin. M.J., 51, $\mathrm{x}$.

LEWIS, T. (I935), "Mlanner in Which Necrosis Arises in Fowl's Comb Under Ergot Poisoning," Clin. Sc., 2, 43.

LEWIS, T. (I94I), "Observations on Some Normal and Injurious Effects $\overline{\bar{\sigma}}$

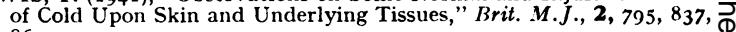
869 .

RICH, A. R. (1942) "Additional Evidence of Role of Hypersensitivity in Etiology of Periarteritis Nodosa; Another Case Associated with Sulfonamide Reaction" Bull. Johns Hopkins Hosp., 71, 375.

RICH, A. R., and GREGORY, J. E. (1943), "Experimental Demonstra- $\overrightarrow{0}$ tion that Periarteritis Nodosa is Manifestation of Hypersensitivity,". Bull. Johns Hopkins Hosp., 72, 65.

Von GLAHN, W. C., and PAPPENHEIMER, A. M. (I926), "Specific $\vec{\omega}$ Lesions of Peripheral Blood Vessels in Rheumatism," Am. J. Path. O

WINTER 235 ITZ, M. C., THOMAS, R. M., and LE COMPTE, P. M. (1938), The Biology' of Arteriosclerosis (Chas. C. Thomas, Springfield).

\title{
A NEW TEST FOR PREGNANCY
}

\author{
By R. E. Elkan, L.R.C.P. \& S.
}

\section{History}

It is now fifteen years since Hogben published a little note in the Proceedings of the Royal Society of South Africa on the relation of the Pituitary Gland to Ovulation and Skin Secretion in Xenopus laevis. Since that time, this toad, so far only known to a few zoologists, has been introduced, first hesitantly and then with enthusiasm, into the physiological laboratories of many countries. Its natural habits and its behaviour in the laboratory-so different from that of other amphibia-have been studied by many authors; it has been bred in large numbers, in London, New York, Basle, Berlin, and elsewhere, and even during the war there has been such a demand for these toads in Cape Town that it is often impossible to obtain supplies. It is fortunate that lately the South African Department for Inland Fisheries has taken an interest in the supply of xenopus. In their country of origin there should be no difficulty of breeding them in large numbers, and experience has shown that, if proper precautions are taken, the transport to London or elsewhere presents no great difficulties either.

\section{Biology}

Xenopus (Fig. I) is classified as a toad of the genus agloss $a$ by the zoologists, but it neither looks even remotely like the toads we know in Europe, nor are his habits similar to theirs. From the laboratory worker's point of view the arrangements that must be made to keep xenopus are more like those required for keeping fish for, like them, these toads spend all their life in the water. $\frac{5}{5}$ This habit makes xenopus even more suitable as $\overrightarrow{0}$ a laboratory animal because they can be kepses, $+\vec{\sigma}$ fairly crowded, in simply constructed tanks an if they are only well fed and supplied with plent? of fresh water they survive, even under laboratory conditions, very well. Indeed, if some of them did not occasionally die through being used for $\frac{Q}{8}$ tests or from infestation with fluke larvae their $\varrho$ life in captivity might be $15^{-20}$ years.

Many observations have been published on the 3 breeding of xenopus in captivity. Aquarists, tired of this "uninspiring" toad that would not breed? in their aquaria, exiled it to a disused tank in the back garden, and after a few weeks found there 3 . hundreds of tadpoles. Imitation rain and change $\frac{5}{3}$ of the $\mathrm{pH}$ have sometimes been successful, sometimes not, and it must be said that without the use of the syringe xenopus is a most capricious breeder in captivity. Under artificial hormonal 은 stimulation; however, it is not difficult to obtain $>$ fertilised eggs and the tadpoles grow up into small frogs during the summer season (Fig. 6). During that No time they can be fed with infusoria, liver emulsion, dried egg emulsion or blood. In a well stocked 0 aquarium, and if not too numerous, they need not $\omega$ be fed at all and can be seen to feed partly after the manner of whales, straining the water through theire gill slits, partly nibbling at the infusorial growth which covers the water plants. Their gills are just? visible, for a day or two after hatching. After that they undergo retrogression and the tadpole has to come to the surface every few minutes for a breath@ 
of air. This habit is taken over through the metamorphosis into adult life. The resting attitude for these toads in the summer is therefore to float, balancing with the long hind legs, just beneath the surface, the nostrils in contact with the air and the body, if possible, hidden by a floating leaf.

Feeding a large population of xenopus has presented a problem in war time. For not only will these toads accept nothing but meat, they even insist that it be perfectly lean, and should the minced meat (horse or other) contain some particles of fat these will certainly be found floating on the surface long after all the meat has disappeared. However hungry, no xenopus will even look at either fat, or carbohydrates. Earthworms, enchytrea, tubifex, flies and liver are more than welcome. Like all reptiles and amphibia xenopus can survive long periods of starvation. He can draw on a fat-body, normally carried in the abdomen and it has been found advisable to let him do this on the journey from Cape Town. Feeding on the journey pollutes the water, particularly in the tropics, and it has happened that the water became so putrid that all the animals died. They can easily be fed back into good form in a few weeks after their arrival here.

Whoever works with xenopus has to learn to distinguish the sexes. In small frogs this is impossible; even in specimen I-2 inches long, doubt sometimes remains because the differentiation depends on labia surrounding the cloacal opening, and these are not always equally well developed. In large mature specimen, however, the labia are easily recognised (Figs. $3 \& 4$ ), particularly if, during a test, they become engorged through hormonal hyperaemia. The males have no external genital organs. Copulation takes place after the manner usual in other species of frogs (Fig. 2). The eggs are fertilised as they leave the female cloaca by the male who is in amplexus with the female. The eggs are deposited one by one and adhere to the water weeds. Hungry males have been seen to gobble up eggs just laid with their own assistance, but I have never yet seen a female eat either her own or another female's eggs.

As to the temperature at which these toads should be kept, $24-26^{\circ} \mathrm{C}$. have been found suitable. The ideal place for keeping xenopus would be a hothouse, permanently kept at this temperature. Failing that, tanks can be constructed with electrical and thermostatically controlled heating. Such an arrangement is definitely required for the "testing tank," a kind of incubator used for the test glasses during pregnancy tests and for the general tanks during the winter months. Low temperatures do the toads less harm than high ones, but if they are to ovulate xenopus must be kept reasonably warm.

\section{Pregnancy Tests}

No test is as yet available for the presence or absence of the foetus; we can only test for the presence of gonadotrophic hormone, produced by the chorionic villi. This hormone is, in its effect, similar to one of the anterior pituitary fractions and in xenopus induces extrusion of ova when injected in sufficient quantity. The reliability of the test therefore depends on the amount of hormone present in a given quantity of urine and the responsiveness of the toad. Both these factors are variable. The urine can be concentrated by the patient if she is advised to refrain from taking fluids on the night before collecting the specimen. Six ounces of morning urine are usually sent in. The responsiveness of the toads depends on several factors, e.g. the temperature at which they are kept, whether they are well fed or not, their age, whether they have previously given positive tests or not and, probably, other unknown factors over which we have no control. It is advisable therefore to use at least three frogs for each test, if possible more.

Several methods have been published to extract urine for the purpose of xenopus tests. The hormone can be precipitated together with other $\mathrm{sub}_{-}$ stances insoluble in alcohol or acetone by mixing the urine with either of these. The precipitate is separated in the centrifuge, the alcohol or acetone removed and the residue extracted with water. The method is quick and simple, but relatively expensive. Another method, published by Scott, which eliminates the use of all inflammable substances was, during war time, found to be an excellent alternative. Here the urine is acidified to $\mathrm{PH}^{4}$. and then extracted with a kaolin suspension. The kaolin adsorbs the hormone and is in turn extracted with sodium hydroxide. The final extract is, in either method, neutralised to make it as harmless to the toads as possible. The hormone is not easily decomposed by alkalies. Specimen which underwent considerable bacterial decomposition in the post and arrived, strongly alkaline and smelling of ammonia, have repeatedly given positive tests.

Of the extract so prepared $\mathrm{I}-2$ c.c. are injected $\vec{O}$ into the toad, either intraperitoneally or into the dorsal lymphsac. The toad is then placed into of a test jar which contains a perforated platform. If the extract contains gonadotrophic hormone either of two results may be expected within $\omega$ 5-24 hours. Either the animals may show a "cloacal reaction" or they may lay eggs. The of engorgement of the cloacal labia is not necessarily a forerunner of the process of ovulation. Ovulating toads often show no cloacal reaction at all and toads showing a cloacal reaction often do not ovulate. The two reactions may be caused by 

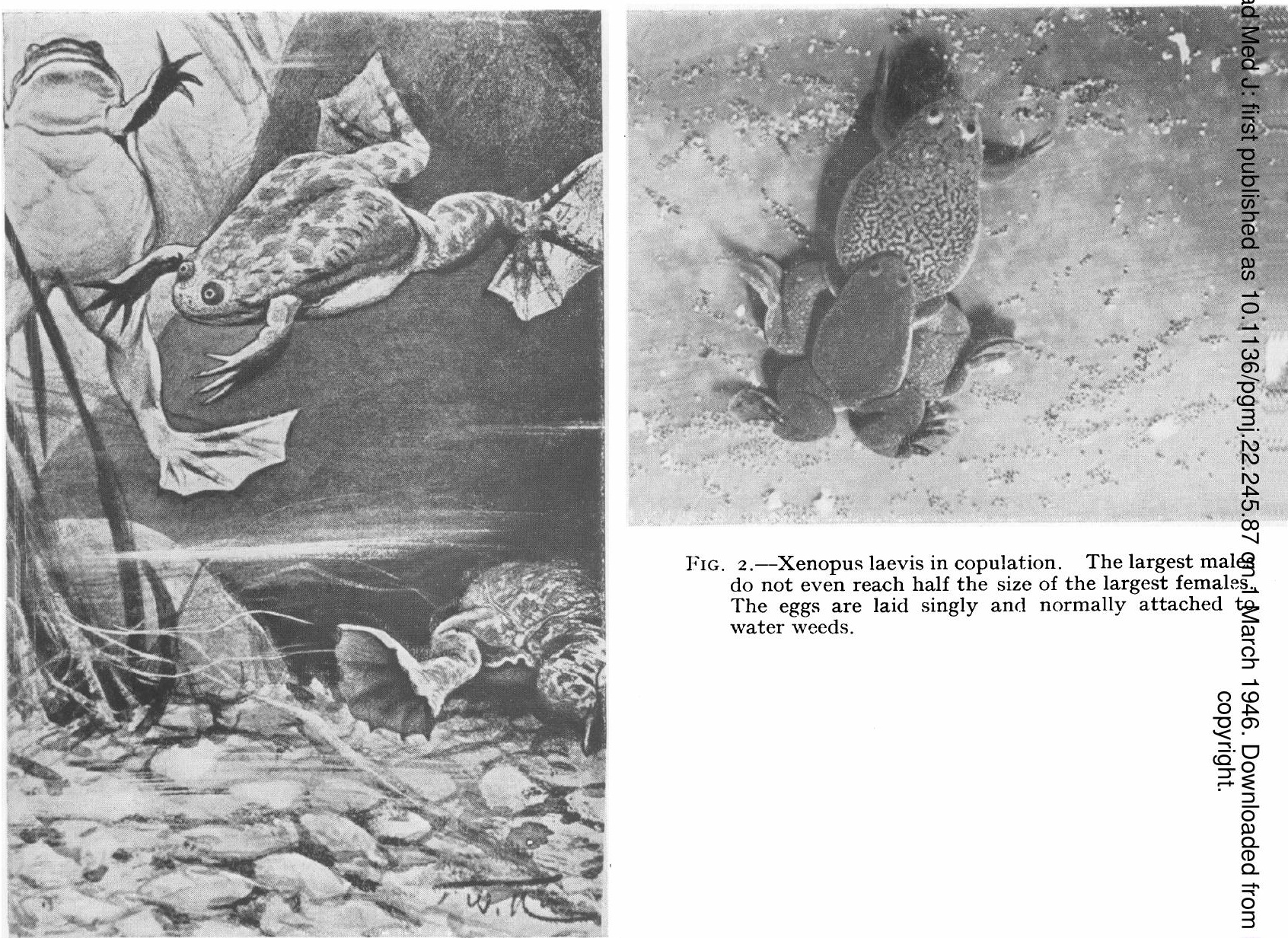

FIG. 2.-Xenopus laevis in copulation. The largest male do not even reach half the size of the largest females. The eggs are laid singly and normally attached to water weeds.

FIG. I.-Xenopus laevis D. The South African Claw-Footed Toad. (Illustration to Brehm's Tierleben, 4I 74 Bibl. Inst. Leipzig and Vienna, I9I 2.)

Fig. 3.-Xenopus laevis. Cloacal region of female. Note presence of clcacal labia.

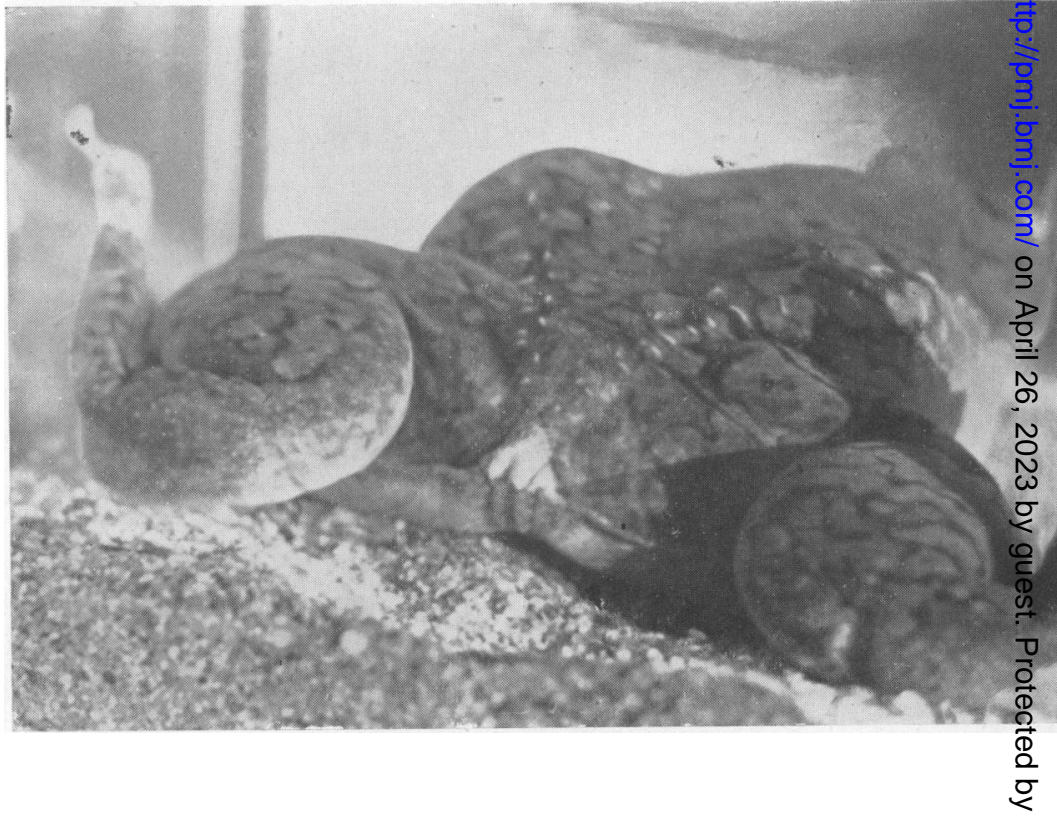




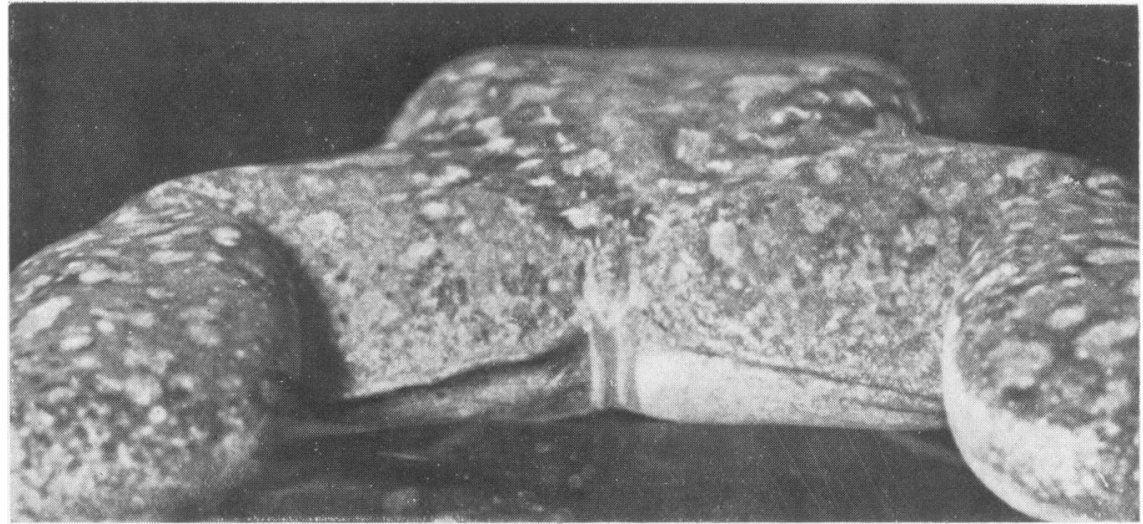

FIg. 4.-Xenopus laevis. Cloacal region of male. Note absence of' all cloacal labia.

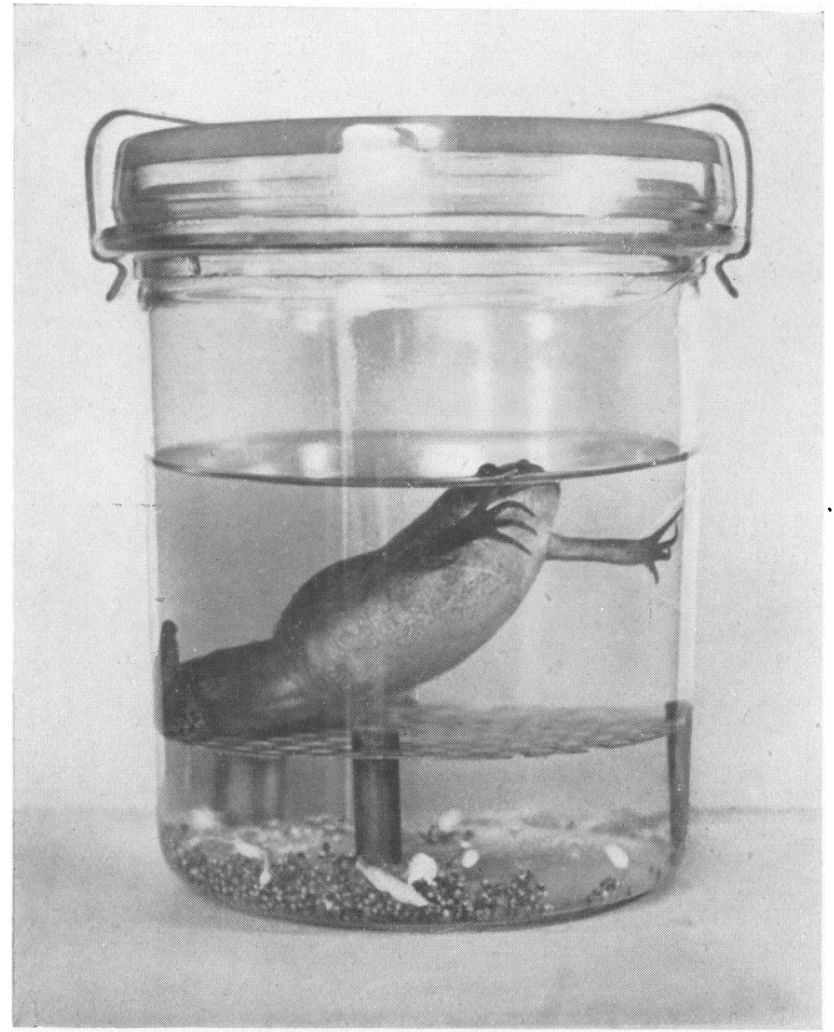

FIG. 5.-Positive pregnancy test with xenopus laevis. The animal has been injected with an extract from the urine to be tested. Eggs are laid in 5-24 hours. The toad sits on a perforated platform and the eggs fall to the bottom of the jar. 
A NEW TEST FOR PREGNANCY R. E. ElkAN, L.R.C.P. \& S.

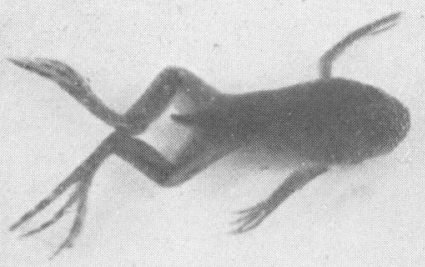

(1)

$\overrightarrow{\vec{D}}$

g
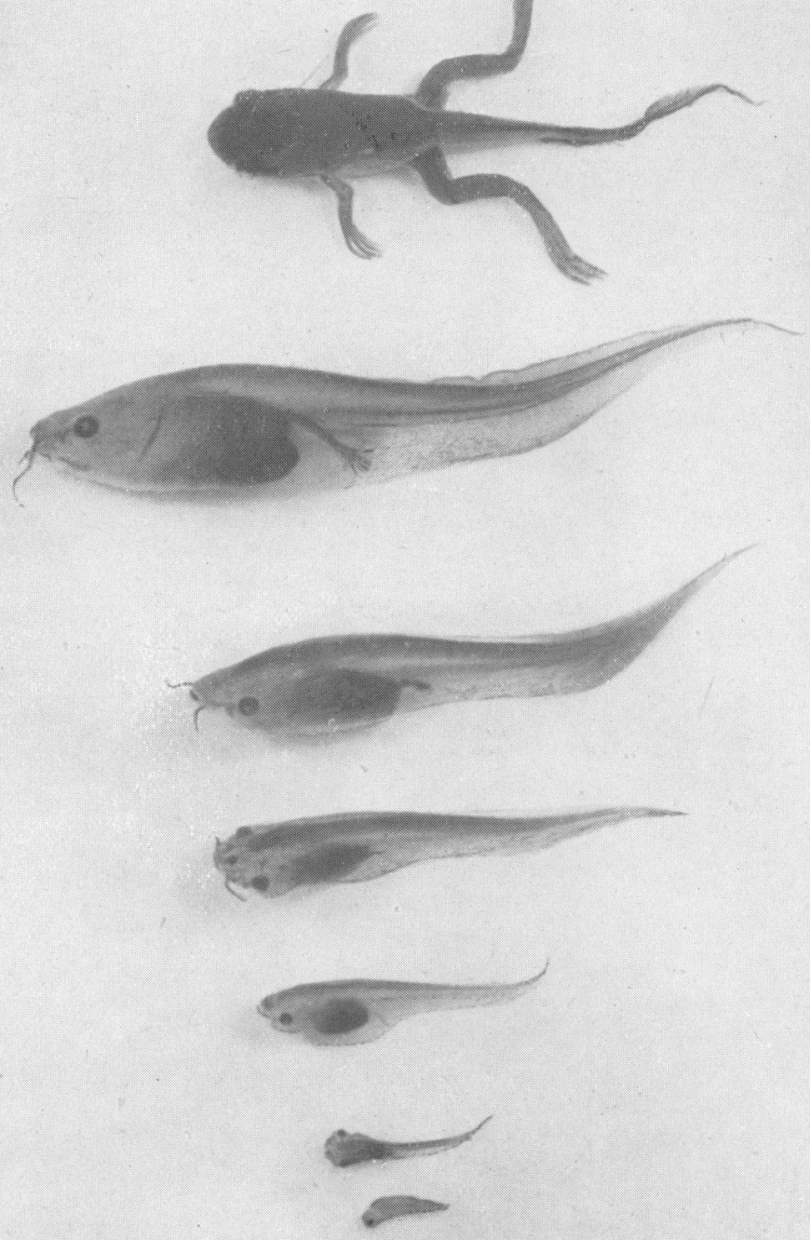

Fig. 6.-Metamorphosis'of Xenopus laevis. The speed of development depends on the temperature of the water and the amount of suitable food available. 
different substances, but they can both be taken as proof for an existing pregnancy. The toads, even if the test should have been negative, should have several weeks rest before being used again. There seems to be no limit as to how often they can be used.

The eggs which are extruded singly or in lumps are covered with a thin layer of sticky gelatinous substance. They either fall to the bottom of the jar or stick to its under side and are easily visible with the naked eye as small spheres, half black half white. Any number of eggs, ranging from I-200 or more, may be produced in positive tests. (Fig. 5).

The xenopus test, relying on the same physiological mechanisms as the Ascheim-Zondek and Friedman tests also equals them in reliability and results must be viewed in the light of what has been said before about the variable factors governing these tests. A positive result can always be taken as a proof of pregnancy, but the amount of gonadotrophic hormone excreted seems to vary considerably and I should hesitate to diagnose a hydatid mole or a chorionepithelioma merely from tests that were positive even in $I: I 0$ or I: 50 dilutions of the normal. Clinical findings must complement the diagnosis in such cases.

Negative results, on the other hand, are often not final. Urines sent in as soon as a clouded conscience prompts the patient may contain no registrable amount of hormone although, at the time, a fertilised ovum is travelling down the Fallopian tube. Even after nidation the newly formed placenta may or may not excrete sufficient hormone to allow for a positive test; all we can say is, that the average pregnancy can be diagnosed from the tenth day after the first missed menstruation onwards, but there are variations in either direction. In case of a miscarriage the test becomes negative as the placenta dies off. Very dilute urines (spec. gravity below I,oro) are difficult to assess. Patients should take no drugs prior to collecting urine and bottles should be meticulously cleaned. Even traces of germicides like T.C.P. are immediately fatal to frogs.

\section{Summary}

The xenopus test, in a series of about 5,000 pregnancy tests, has proved to be of a reliability sufficient to make it a valuable help to clinicians. It is deplorable, perhaps, that the laboratory should be a separate unit, not in close contact with the patient or her doctor, because much valuable information could be obtained from closer collaboration. But the test is so simple that, when normal times and conditions again prevail, there is no reason why obstetric departments should not $\mathrm{c}$ have a xenopus laboratory of their own, and in such a side room pregnancy station much interesting information could indeed be collected by workers equally interested in the biology of this peculiar batrachian and the physiology of their patients.

\section{BIBLIOGRAPHY}

ALEXANDER, S., and BELLERBY, C. W. (1935), J. Exp. Biol., 306. ALEXANDER, S., and BELLERBY, C. W. (1938), J. Exp. Biol.

BEDDARD, F. E. (1894), Proc. Zoo. Soc.

BELLERBY, C. W. (I929), J. Physiol, 67, Proc. XXXII.

BELLERBY, C. W. (r933), Biochem. J., 27, 2022.

BELLERBY, C. W. (1934), Nature, March 3 Ist, 494.

BELLERBY'C. W., and HOGBEN, L. (1938), J. Exp. Biol., 15, No. I.

BERK, L. (1938), S. Afr. Med. J. Med. Science, 3.

BLES, E. J. (1906), Transact. Roy. Soc. Edin., 41.

BLES, E. J., Proc. Cambr. Phil. Soc., 11.

BOSMAN, L. P. (I937), Brit. Med. J., 2, 939.

CREW, F. A. E. (1936) Brit. Med. J., 2, 1092.

CRFW, F. A. E. (1937), Brit. Med. J., 2, 1044.

CREW, F. A. E. (1939), Brit. Med. J., 1, Apr. 15 th.

ELKAN, R. E. (1938), Practitioner, 140, 312 .

ELKAN, R. E. (r938), Brit. Med. J., 2, 1253

ELKAN, R. E. (I939), Aquarist, May I939.

GASCHE, P. (1943), Rev. Swisse de Żool., 50, 262.

HOGBEN, L. T. (1930), Proc. Roy. Soc. S. Afr.

HOGBEN, CHARLES, and SLOME (I93I), J. Exp. Biol., 8, 345.

HOGBEN, L. T. (1939), Brit. Med. J., July Ist.

LESLIE, J. M. (1890), Proc. Zool. Soc., 69.

ORENT, E. R., and McCOLLUM, E. V. (1931), J. Biol. Chem., 92, 651. ROSE, J. M., A nnals S. Afr. Mus., 20, Pt. 6.

SCOTT, L. D. (1940), J. Exp. Pathol., 21, 320.

SHAPIRO, H. A., and ZWARENSTEIN, H. (1933), Proc. Roy. Soc. S. $4 \mathrm{fr}$., Sept. 2oth.

Afr., Sept. 20th.

SHAPIRO, H. A., and ZWARENSTEIN, H. (r933), J. Exp. Biol., 10, 372 .

SHAPIRO, H. A., and ZWARENSTEIN, H. (I934), Nature, 133, May Igth.

SOUTHWELL and KIRSCHNER, A. (1937), Ann. Trop. Med., 31, 245.

WEISMAN, A. I. (1938), Amer. J. Obst. and Gyn., 35, 345.

WEISMAN, A. I., and COATES, C. W. (1944), Research Bulletin N. Y. Res. Found.

ZONDE K, B. (1930), Klin. Wochenschr., 9, 964.

ZONDE K, B. (1935), Hormone des Ovariums, etc., Springer, Vienna, 567. ZWARENSTEIN (1937), Nature, 139, Jan. I6th.

For further literature see Weisman, A. I., and Coates, 1944 